\title{
Students' Perception on Peer Revisions of Deemphasizing Grammar Correction in SMA Mulia Bhakti, Makassar, South Sulawesi
}

\author{
Jelita Purnamasari \\ purnamasari.jelita@yahoo.co.id \\ Baso Jabu \\ basojabu@unm.ac.id \\ Abdul Halim \\ abdhalimmhum@yahoo.com
}

State University of Makassar, Indonesia

\begin{abstract}
This researc aims at (i) investigating perceptions of learners about the implementation of peer revision of deemphasizing grammatical correction at SMA Mulia Bhakti Makassar, (ii) finding out the factors which influenced the implementation of peer revision of deemphasizing grammar correction at SMA Mulia Bhakti Makassar, and (iii) finding out how the peer revision of deemphasizing grammar correction is implemented at SMA Mulia Bhakti Makassar. The researchers conducted qualitative method. The data resources were $11^{\text {th }}$-grade students at SMA Mulia Bhakti Makassar who had experience in the practice of peer revision of deemphasizing grammar correction. The result showed that, (i) the researchers found the students' positive perception and negative perception on peer revision of deemphasizing grammatical correction. The positive perceptions were students became more active, developed their critical thinking, leaded them to students' self-directed learning, and decreased students' writing apprehension while the negative perceptions were it created overly critical comments and also conflict (ii) the factors influenced the implementation were students' ability as reviewer and sitting them in collaborative work (iii) the steps of peer revision of deemphasizing grammatical correction at SMA Mulia Bhakti Makassar consisted of six steps, namely writing, revision, first rewriting, editing, second rewriting, and scoring.
\end{abstract}

Keywords: perception, peer revision, grammar correction

\section{INTRODUCTION}

Teaching EFL writing is regarded as a challenging job for EFL teachers relating to the complexity of writing itself such as learning to write in a new language, students generally learn the grammar, syntactic structure, vocabulary, rhetorical structure, and idioms of a new language. Besides, students who are not "familiar" with writing activities, composing a text could be already difficult for them. 
Despite the difficulties attached to writing, writing has to be taught for EFL students - as well as other skills such as listening, reading and speaking - because writing has some contributions in their language development. It provides an opportunity for students to develop their communication skills in written way.

Besides, teachers have to realize that writing is not just about putting words on a paper rather than organizing them into well-written text which aims at conveying the message for the readers. Thus, this is a highly demanding process of writing to develop students writing skill. Unfortunately, most of the teachers only focus on the final product of the students. Besides, the teaching of writing skill, traditionally, seems as teacher dependent. To avoid that, a teacher should establish an atmosphere whereby the students must learn as a result of their own efforts in which teachers' role is only as a facilitator in students' learning. Then, students can be self-motivated with a curious nature and rely more on themselves and less on the teacher. One way to adjust this pattern of teaching and learning is to give the students more responsibility for their own learning.

According to Hyland (2002), he claims that peer revision encourages students to participate in the classroom activity and make them less teacher-dependent. In the process of peer revision, students discuss each others' draft by commenting and criticizing. Therefore, students get an opportunity to be active in the teaching and learning process. They will become more independent in learning. Therefore, peer revision could be one of writing instruction who could help the teacher in teaching writing especially in EFL writing.

In Indonesia, the problem commonly reveals in an English writing class is that the students tend to focus too much on the aspects of grammar (Sukandi, 2014:146), neglecting the basic essence of learning writing whereby students not only learn the grammar but also how to compose meaningful and logical text order in the target language.

Teachers need to engage students to write in the sense of their own "style" and let them go their own thought in writing. Otherwise, the teacher only produces "robotic writers" by means good in grammar but worst in ideas. According to Gray (2004), there is little connection between correction and learning in which those who do not receive less grammar correction have a more positive feeling about writing than those who did. 


\section{4| ELT Worldwide Vol. 3 No. 1 April 2016}

Besides, focusing on grammatical efforts tends to sidetrack students from issues such as organization and logical development of content. Thus, the correction of writing has to be controlled by the teachers which not only focus on the grammar but also the ideas of the text.

Peer revisions which the peer correction activity is not focused on the grammar rather the discussion of ideas. The activities which have been conducted for around six months at school is one of writing instruction which adopts a communicative learning concept. As Brown (2007) stated that communicative learning is one of language learning approach that emphasizes authenticity, interaction, learner-centered learning, task-based activity, and communication for real-life. Traditionally, the teaching and learning writing is regarded a less communicative and innovative, resulting in lack of student interesting writing. Besides, in the process of teaching writing, students only focus on grammar or structure rather the ideas of the text. Therefore, it is valuable to explore the activities of peer revision of deemphasizing grammar correction by conducting this qualitative research.

\section{LITERATURE REVIEW}

\section{Peer Revision}

Peer revision refers to peer feedback which is known as under different names such as peer response, peer revision, peer review, and peer evaluation (Bijami, 2013). Further, there are some opinions toward its definition which is drawn by some experts. Bartels (2003: 34) defines it as an activity where "learners read each other's peer papers and provide feedback to the writer". Hansen et al (2005) also add the use "peer revision' where the learners used as a source of information for each other in commenting or criticizing others' draft. According to Topping(2000), peer revision is understood to mean the educational arrangement in which learners consider or evaluate the value, quality or success of work produced by their fellow learners and provide each other with feedback. In brief, it is an activity in which learners receive feedback about their writing from other learners who are their peers (Richard et al, 2002). While, according to Fallows (2001), it means "a shift away from traditional assessment which the corrections are only the role and responsibility of the teacher" but, it allows learners to "take an active role to manage their own learning in writing". 


\section{Peer Revision and Writing Process}

According to Harmer (2004), writing is a process which includes the sequence of steps such as generating ideas, drafting, revising, editing, and publishing. It is important for learners to go through all of the steps in the writing process because every stage has its own importance to build learners writing. The explanations of each stage of the writing process as follows:

1) Generating ideas (Pre-writing)

In this stage, it gives an opportunity for the learners to get ready to write. Learners are asked to gather information and to experiment with the ideas. Pre-writing is a process before a single word at the same time, learners decide to write. It encourages the learners to plan their writing. The reasons why learners have to be in this stage firstly, think of this like mapping out a road trip. No one would drive out of state for the big game without a map in which who knows where the person would end up? Thus, the same is true of writing paper whereby learners must have a plan in order to decrease any possible problems would exist.

\section{2) Drafting}

At this stage, the learners will focus on the fluency of writing and write without having much attention to the accuracy of their works. During the process of writing, the learners must also focus on the content and the meaning of the writing. Besides, during this stage, the learners translate their thoughts and ideas into sentences and paragraph. It should be done with a particular purpose and audience in mind.

\section{3) Revising}

The next step in process writing is a revision. According to Harmer (2004: 5), it is the time when the draft is finished and the writer rereads it to find out possible mistakes connected both with the content and accuracy. Further, Harmer (2004: 5) specifies possible problems within a text, for instance, an unclear order of information, and ambiguous or confusing parts of the text. He also says that: "more skilled writers tend to look at issues of general meaning and overall structure before concentrating on detailed features such as individual words and grammatical accuracy"(Harmer, 2004: 5). 
4) Editing

During the editing phase, the writer focuses on the conventions of language. Spelling, punctuation, syntax, and structure are analyzed and corrected. The learners should have access to dictionaries, thesauruses, style sheets and another reference material at this stage.

\section{5) Publishing}

The stage of publishing is the final step. During this stage, the learners learn how to present their work to the public. Decision-making in the field of artwork, the media of presentation (handwriting or printing), or even reading the text for the audience are closely connected with this stage. The teacher should outline some ways of publishing and discuss them with the learners. The way of publishing can be highly individual matter and what is more, the learners might be invited to develop their own ways of publishing to make the text visually attractive for the reader. Creativity, independence, and self-expression are essential for this stage. The final versions can be presented orally by reading in the classrooms, displayed in the library, or broadcast worldwide.

\section{Peer Revision as Collaborative Writing Activities}

Collaborative learning is a situation in which two or more people interact with each other to trigger learning mechanisms (Dillenbourg, 1999). Collaborative learning as a system of teaching and learning techniques underlying the communicative language teaching emphasizes active interaction between learners with different skills and background knowledge. In the same line, Kurt (2007) claim that knowledge is negotiated and best acquired through interaction. Along with the shift from the teacher-centered to learner-centered classrooms, group work has applied to learning contexts with the aim of increasing communication and interaction. Peer feedback provides opportunities for the learners to negotiate meaning, to give comments and suggestions, and to make corrections so that they can find their strengths and weaknesses.

\section{Peer Revision of Deemphasizing Grammatical Correction}

Peer revision of deemphasizing grammatical correction is one of writing instruction in which students comment each others' written draft, however, they only comment on the ideas or organization. In this practice or revision, students do not emphasize to correct their grammar. 
Many researchers have found that a strict adherence to the "grammar corrections only" approach to ESL learning is truly not effective. It's been found, for example, that grammar rules tend to be woven instinctively into language use patterns. It is more important to see what learners are trying to say - i.e. their ideas, than to concentrate on how they are saying it.

Many studies claimed that grammar correction to second language learners is discouraging and even harmful. Cohen (1987) indicated that focusing on grammatical efforts tends to sidetrack learners from issues such as organization and logical development of content. Learners regularly do not incorporate such corrections into their work.

\section{METHOD}

This research employed descriptive qualitative by applying case study approach at the SMA Mulia Bhakti, Makassar. This research used Miler and Huberman (1994), that Reduction, data display, and verification.

\section{Participants}

The participants of this research were $11^{\text {th }}$-grade students of SMA Mulia Bhakti Makassar. There were eighteen students who those have been involved in the practice of the peer revision of deemphasizing grammatical correction.

\section{Collecting Data}

The data were collected from self-report and interview, as follow:

Firstly, the data were collected by asking the participants to think and recall their experience about their writing English experience using peer revision of deemphasizing grammatical correction, and to describe the process of peer revision of deemphasizing grammatical correction and what their feeling about conducting this method. The researchers asked the students to make self-report by writing their experience about the implementation of the peer revision of deemphasizing grammatical correction at their school-SMA Mulia Bhakti Makassar, but before that the students were informed about the nature and the objective of this research.

Second, some interviews were conducted with some selected participants; face to face interviews were also conducted to have more details and deeper explanation about their perception. 
38| ELT Worldwide Vol. 3 No. 1 April 2016

Besides conducting self-report and interview, the researchers also conducted field notes along the process of collecting data. In this study, the researchers observed the situation of the implementation of peer revision of deemphasizing grammar correction at SMA Mulia Bhakti by taking a note. The observation was conducted without disturbing the class activities in order to let it run naturally as usual.

\section{Results}

Based on the data gathered, the researchers found some perceptions regard to the implementation of peer revision of deemphasizing grammatical correction at SMA Mulia Bhakti Makassar. Therefore, the researchers categorized the perceptions some aspects:

\section{a) Creating active learning}

Active learning refers to the situation of teaching and learning where students do anything in a classroom other than merely passively listening to a teacher. Regarding with this point, the researchers found that peer revision of deemphasizing grammar correction at SMA Mulia Bhakti created active learning. As stated by student (SRT) in self-report conducted on May $26^{\text {th }}, 2015$ :

Kelas menjadi lebih aktif dengan berdiskusi bersama. (the class became more active with discussion activity)

Based on the statement above, the active situation was created by the discussion. The discussion which conducted in writing class was seen as a good point where it could change the situation become active. The phrase of "discussions" is also implied that the writing activity was covered by the students' participation at SMA Mulia Bhakti Makassar which made the class more active.

\section{b) Developing critical thinking}

Critical thinking is a conscious and deliberate process that is used to interpret and evaluate information and experience with a number of reflective attitudes (Mertes, 1991). In this point, the researchers found that the peer revision of deemphasizing grammar correction led students to become critical thinking. As the confession from the students, through this activity, they got an opportunity to reflect their writing. As stated by the student (DA) in self-report conducted on May $26^{\text {th }}$, 2015below: 
Purnamasari, Jabu, Halim : Students'

...bisa mengetahui apakah teks yang kita buat bagus atau masih banyak kendala (able to know whether the text that I wrote was good or need more correction)

The lines above inform that the student made the analysis toward the text. So, the student tried to understand their written text. It is one of effort that could lead her to be critical thinking.

\section{c) Leading to Students' self-directed learning (SDL)}

Self-directed learning (SDL) refers to student-centered learning that relates to the change in focus in the classroom "from the teacher to the student" or "from the teaching to the learning". For example, selfdirected is when students realize that gaining knowledge is not about how much the knowledge that the teacher gives to them in the class activities but it prefers to how much their efforts to gain knowledge in anywhere, from whoever, in their own way in absorbing the knowledge. Therefore, it is called from teaching to learning whereby students are not dependent on teachers.

In this case, the researchers found that the statements of students which indicate that the peer revision of deemphasizing grammar leads them to self-directed learning. The students (GR) stated in self-report which conducted on 26 May 2015, "Dengan berinteraksi dengan teman, saya bisa belajar member pendapat dan bagaimana menulis yang baik" (with interaction each others, I learned in giving opinion and learned how to write in good). From this statement, she tried to make interaction with her peer and learned from this way, in which she learned to be not too much dependent on the teacher. It is a good point, in which students learned how to solve their own problem.

\section{d) Decreasing students' anxiety in writing}

In this research, the researchers found that peer revision of deemphasizing grammatical correction decrease students' anxiety in writing. As stated by the student (SL)in self-report which was conducted on $26^{\text {th }}$ May, 2015:

Saya merasa tidak tertekan dalam menulis karena saya berdiskusi dengan teman

(I felt not in pressure in writing because I discussed with my peer)

Thus, from the statements above the writing activities was not frightening for the student. It informed that the students were in positive feeling. 
40| ELT Worldwide Vol. 3 No. 1 April 2016

\section{e) Creating overly critical comments}

In this research, the discussion each others' text that conducted in the peer revision of deemphasizing grammatical correction, require students to comment and criticize someone's ideas. In this case, the risk of this correction could lead problem, as stated by RAFR below:

"Saya tidak suka dengan komentar teman yang terlalu berlebihan tentang tulisan saya. saya juga memilih-milih komentar yang diberikan teman, karena biasanya komentar yang diberikan tidak sesuai dengan yang saya harapkan. ("I did not like over comments on my written text. I did "picking" the comments that was given from my peer, because they seemed not as I expected.")

From the statements above, RAFR did not like when he met a peer that comment his text over critically.

\section{f) Creating conflict}

As stated above, the implementation of peer revision of deemphasizing grammar correction created over critical comment. Further, from the data gained, the researchers found that the implementation of deemphasizing grammar correction could made conflict among students, it is implied from student(SL) perception as stated below:

"ketidak kompakkan dan saling tidak mau mengalah, kadang saya harus diam dan menerima pendapat teman saya. Jadi kendala yang saya alami adalah jika mendapat berbedaan pendapat" (the lack of corporative attitude and students did not budge each other, sometimes I should be silent and accept my peer's opinion, so the problem that I face is if there is some contrary opinions)

Based on the data above, the researchers found that the cause was the discussion ideas that they did. However, discussion commonly present the conflict between students, however discussions ideas would be a risk if teacher do not make a rule or advise in making motivating comment.

\section{How the peer revision of deemphasizing grammatical correction implemented at SMA Mulia Bhakti Makassar}

The process of peer revision of the deemphasizing grammatical correction has been conducted by the teacher at SMA Mulia Bhakti Makassar. Based on the theory, there are two types of peer revision method. In this research, the researchers s found the distinctive between the method applied and the theory. 
From the data collection of students' self-report, the researchers found that the process of peer revision of the deemphasizing grammatical correction consisted of some steps, as follow:

The process of writing consisted of:

- Writing a text that the teacher asked

- Sitting in two, for discussing our text each other (first, we read the text, and then we comment on the content of the text)

- Giving back our text to each other and rewrite the text that has been commented

- Collecting the text that already rewrite to the teacher

- The teacher correct our text's grammar

- He returns our text and asks to rewrite again

- Finally, we collect to the teacher for scoring" (Self-Report, 26 ${ }^{\text {th }}$ May, 2015)

Based on the data, the process of peer revision of deemphasizing grammatical correction which was implemented at SMA Mulia Bhakti Makassar consisted of six steps namely writing, revision, rewriting, editing, rewriting, and scoring.

\section{Discussion}

As revealed previously, limitation of students was a problem in the process of the implementation of peer revision of deemphasizing grammatical correction at SMA Mulia Bhakti Makassar. In this case, the limitation perceived as the limitation of peers as reviewers in which some students had a problem to critique another student's writing.

Consequently, when students felt isolated by this situation that they face, and teacher does not recognize it wisely, they may lose interest interests and create their incorporation attitude. According to Rollinson, the lack of training for students toward method could lead them to the unsuccessful in learning, which can lead to students' negative views and they may not fully participate in this method.

From this case, the students need to be trained more about how to make productive comments. As stated by $\mathrm{Hu}(2005)$ :

"students training and careful implementation of peer review have been recommended in the literature as an effective means overcoming the problems associated with the classroom use of peer review and of improving its pedagogical effectiveness" (p.321) 


\section{2| ELT Worldwide Vol. 3 No. 1 April 2016}

It is valuable to be realized that the problem was led to students' incorporation was their ability in making a constructive comment. Hence, in this case, they need to be trained. The training could raise their awareness about the importance of making a constructive comment. Such awareness-raising can help students develop an appropriate attitude toward peer revision (Berg, 1999).

Inappropriate pedagogical implementation of peer revision of deemphasizing grammatical correction can also negatively affect students' attitudes toward it. In this case, students felt comfortable in performing certain peer review activities implemented inadequately. Students with lower proficiency in the target language felt inhibited in contributing to the task in groups with mixed proficiency levels.

From the data indicate that they did not know what to look for in peer's drafts or fail to give usable comments. For instance, in giving a comment on ideas of the text, they tend to give general and vague comments rather than specific one. Consequently, this caused a lack of productive corporation activities. This situation led them into a negative perception and later further influence their attitude toward this instruction. As stated by Addler (2015), the one's perception can affect their act toward something. This study revealed that some students' statements said that they did not like to work together with their peer when they got a partner who had problems in giving comments. Therefore, from their negative perception toward peer revision of deemphasizing grammar correction, affect their behavior and attitudes and they discouraged peer collaboration.

Based on the findings explained, the process of peer revision of deemphasizing grammatical correction at SMA Mulia Bhakti Makassar consisted of seven steps which will be explained below:

Step 1: drafting \& writing

Based on the data, got from self-report and classroom observation, the activity starting with drafting and writing. The students were asked to generate their ideas and then transferring it into written text. From the classroom observation done by the researcher, there is no any special treatment that did by the teacher to help students in generating their ideas. However, in this activity, the activity of drafting and writing is not fully conducted in one meeting. Students got time to finish their text at home. 
Step 2: Revision

After the students finished with their writing, the students were asked to sit with a classmate. This activity was controlled by the teacher where the teacher chose who would sit with who. The teachers divided them into 6 groups; each group consists of two students. In this step, the students who already sat in group revised each other's text. The detailed process of revision was conducted through some activities. Before revising, the students were asked to read the text first, after that they comment each others' draft.

Step 3: Re-write

After revising each others' draft, the students rewrite their text that had been discussed with peers.

Step 4: Teacher correct on grammar (editing)

In this step, the teacher corrects all the students' text, however, the teacher only corrects the grammar.

Step 5: Re-write

After the teacher corrected the grammar, students were given an opportunity to rewrite again, and this was their final writing.

Step 6: Teacher Scoring

The final step was evaluation. In this step, teacher scored the students text.

\section{The process of peer revision of deemphasizing grammatical correction}

Base on the explanation above, the researchers found that this method is one of an innovative way. Generally, during the process of peer revision of deemphasizing grammar correction, students did not only write a text, but also correct (criticizing and commenting) their text. It is a valuable thing which the correction which was done by them led them to be more aware of their learning, especially in learning writing, As stated by Shokrpur (2003), by doing this activity students are engaged to improve their writing by their selves in frequent reading and writing as well as fostered their critical reading and reflection. From the data obtained that, these activities consisted of six stages, namely writing, revising, rewriting, editing, rewriting, and scoring. 


\section{4| ELT Worldwide Vol. 3 No. 1 April 2016}

Starting with writing, where students are given the time of the teacher to write, but this activity is not carried out fully in class, but the students are given time to finish writing at home. This is a good point of this activity, because of teacher indirectly try to change the students' perception that writing is not like a test that they have to finish within a "short" time. According to Karjalainen (2015), the time provided for independent work is the resource allocated for the actual learning process. Writing is a complex activity, and it takes time for putting ideas into a written text. Allowing students to write at home is one way to avoid stereotypes that learning to write is like a test which they have to finish their writing at that time. Hence, it is important to be known that giving students more times to write is not put them in the pressure of learning, where students do not have to create text in a "rapid" time otherwise the text does not cover the message that they want to convey.

Revising was the core activity of this method. In this study, researchers found that the correction done by the students in revision, not on grammar but on text's ideas and others' aspect of content such text organization and vocabulary. Learning writing especially for those who are learning to write in a foreign language cannot be separated indeed from the aspects contained therein such as grammar or organization of ideas, etc. The complexities of writing, it is frequently brought to conflict pedagogy in teaching and learning of writing. It creates a dichotomy that which aspect is more important for students. For instance, Cohen (1987) indicated that focusing on grammatical efforts tends to sidetrack learners from issues such as organization and logical development of content. While (2011) stated that grammar is a framework that could make the story stands. Nevertheless, this issue essentially should be considered careful in a contextual way. If the root of the students' writing problem is pouring their ideas into written text, therefore they have to be practice to write firstly. The teacher needs to engage them in writing habit and, of course, the teacher needs to create an enjoyable situation to engage them. In another side, the ability to correct grammar is insufficient; therefore, it must be thought wisely about what students' needs in learning writing should be. Therefore, the concept of ideas discussion could be one of the ways to assist them in writing activity. In this study, from the data obtained revealed that students benefit from these activities, which they claimed that by talking about their ideas made them became more aware of how pouring ideas in written text. 
In this case, the phenomenon occurred in this section that some students were incorporative with their peer because their ability as a reviewer was limited and also the comments were given too critical. Based on the data, the researchers found that the cause of this problem is that the revision was conducted without any model to be shown to the students. Consequently, this condition created a problem which was some students could not give a constructive comment to their peer. Whereas, if giving comments was the "core" activity of this method that aimed to change students' attitude toward learning writing which used to be less communicative and difficult, it is a crucial thing to the teacher to motivate all of the students in writing.

As explained above, students need a model; giving them "guidance" is one of the solutions in which students are taught how to make a good and constructive comment. Besides, giving them a model actually can help the students to make a constructive comment and help the teacher to control them in making comments which aim to decrease the overly critical comment.

Afterward, editing was the next section in which the students had finished rewriting their text after revision. Based on the data obtained, the editing was done by the teacher. In this method, the editing refers to the activity in which the teacher corrects the grammar error of the students' written text. It is also a good point, in which the teacher tried to avoid the students' negative attitude towards writing. According to the research (Sukandi, 2014), the most problem of in learning writing is that the students and the teacher too much focus on the grammar error rather than the content of the text. Therefore, the decision was made by the teacher is an already good thing, because it change the stereotype that when the students learn writing, they only focus on not only the students' grammar error but also the content of their text. Afterward, the teacher asked the students to re-write their text again.

Finally, the last section of this method was scoring. The scoring was done by the teacher. Giving students scoring is one of the ways to respect their effort in learning. Therefore, scoring students' text is an important thing to let them know about their "achievement" in learning.

In addition, the activity of peer discussion was efficient since teacher could save their time to teach. Involving students in teaching and learning process could be one of the solutions when the materials at school seemed overloaded. For instance, English teachers have to teach four skills in one semester. Therefore, this activity could one of solutions in teaching writing. 
46| ELT Worldwide Vol. 3 No. 1 April 2016

\section{Conclusion and Suggestion}

\section{Conclusion}

1. Based on the data description, the researchers found that the positive perception and negative perception of students on peer revision of deemphasizing grammatical correction. The positive perceptions found by the researchers that the implementation of peer revision of deemphasizing grammatical correction made students more active, develop their critical thinking, lead them to students' self-directed learning, and decrease students' apprehension in writing, while the negative perceptions found those were it created overly critical comments and it also created conflict.

2. The factors that influenced the implementation peer revision of deemphasizing grammatical correction were students' capability as reviewers and sitting them in collaborative work.

3. The steps of peer revision of deemphasizing grammatical correction at SMA Mulia Bhakti Makassar consisted of six steps namely writing, revision, rewriting, editing, rewriting, and scoring.

\section{Suggestion}

1. Since the problem occurred that some students face difficulty in making constructive comments, therefore the researcher suggest to make training about how to make constructive comments.

2. Teachers need more be sensitive with students' relationship because commenting or criticizing someone's text frequently damage motivation in writing, therefore, a teacher should carefully seat them in a group.

3. Departing from the issue of learning writing in school in which just merely corrects on grammar and the ideas discussion seemed to ignore by some teachers, the research expects that for further research could do the experimental research to this issue.

4. For further research, it is recommended to conduct this kind activity in a higher level such as at University level. 


\section{REFERENCE}

Ali, S. et al. The Effects Of Peer Feedback On EFL Learners' Writing Performance.pasca.unhas.ac.id/jurnal/files/0ffcb9823109fb1483 1c5933c2c5f4c5.pdf Retrieved on February, 4, 2015.

Angell, J. 1906. "Perception", Chapter 6 in Psychology: An Introductory Study of the Structure and Function of Human Conscious, Third edition, revised. New York: Henry Holt and Company.https://www.brocku.ca/MeadProject/Angell/Angell_1 906/Angell_1906_f.html retrieved on June 2015

Bartels, N. 2003. Written peer response in L2 writing. English Teaching Forum, 4: 34-38.

Berg, E. C. 1999. The effects of trained peer response on ESL learners' revision types and writing quality.Journal of Second Language Writing, 8, 215-241.

Bijami, M. 2013. Peer Feedback In Learning English Writing: Advantages and Disadvantages. Journal of Studies in Education, 3(4), pp. 91-97.

Brown, Douglas H. 2007. Principles of Language Teaching and Learning. London: Pearson Education Inc.

Cohen, A. D. 1987. Student processing of feedback on their compositions. In A. Wenden, \& J. Rubin (Eds.), Learner Strategies in Language Learning (pp. 55-69).

Cooper, M. M. 1986. The Ecology of Writing.College English, 48, 364-75.

Dillenbourg, P. 1999. Collaborative learning: Cognitive and computational approaches. Advances in Learning and Instruction Series. New York, NY: Elsevier Science, Inc.

Fallow, S. et al. 2001. Multiple approaches to assessment: reflection on the use of a tutor, peer, and self-assessment. Teaching in Higher Education, 6(2), pp.331-351. 
48| ELT Worldwide Vol. 3 No. 1 April 2016

Gray, R. 2004. Grammar correction in ESL/EFL writing may not be effective. TheInternet TESL Journal. 10(11)

Hansen, J. et al. 2005. Guiding Principles for effective peer response.ELT Journal, 59: 31-38.

Haran, M. 1992. A Survey of the Writing Approaches Followed by ESL Teachers in Port Elizabeth Secondary Schools Where Afrikaans is the First Language.

Harmer, J. 2004.How to Teach English. London: Longman.

Hill, B. 2011. On Grammar and Punctuation. http://theeditorsblog.net/2011/05/30/on-grammar-andpunctuation/, retrieved on June 2015

Hu, G. W., \& Lam, S. T. E. 2010. Issues of cultural appropriateness and pedagogical efficacy: Exploring peer review in a second language writing class. Instructional Science, 38, 371-394.

Hyland, P. 2000. ESL writers and feedback: Giving more autonomy to learners. Language Teaching Research, 4(1), pp.33-54.

Jahin, J.H. 2012.The Effect of Peer Reviewing on Writing Apprehension and Essay Writing Ability of Prospective EFL Teachers.Australian Journal of Teacher Education, 37(11), pp. 61-84.

Karjalainan, A. 2006. Give me time to think. Finland: Oulu University Press. http://www.oulu.fi/w5w/tyokalut/GET2.pdf, retrieved on June 2015.

Kurt, G. 2007. The effects of peer feedback on the writing anxiety of prospective Turkish teachers of EFL.Journal of Theory and Practice in Education, 3(1), 12-23.

Lam, R. 2010. A Peer Review Training Workshop: Coaching Learners to Give and Evaluate Peer Feedback. TESL Canada Journal, 27(2), pp. 114-127

Lee, N. S. 2009. Written peer feedback by EFL learners: Praise, criticism, and suggestion. Komaba Journal of English Education, 1, 129-139. 
Purnamasari, Jabu, Halim : Students'

Lin, G.H.C. 2009.An Investigation into Effectiveness of Peer Feedback.Journal of Applied Foreign Language Fortune Institute of Technology, 3:79-87.

Lundstrom, K. et al. 2009. To give is better that to receive: The benefits of peer review to the reviewer's own writing. Journal of Second Language Writing, 18, pp.0-43.

Mahmoud, A. 2012. Strategy-based Peer Assistance in EFL Writing: An Alternative to Traditional Peer Correction. Journal of Theory and Practice in Language Studies. Vol.2 No. 10, 19871992.

Miao, Yang. Et al. 2006.A comparative study of peer and teacher feedback in a Chinese EFL writing class.Journal of Second Language Writing.15 (179-200)

Nelson, G. et al. 1992. An L2 writing group: Task and social dimensions. Journal of Second Language Writing, 11: 171-193.

Ningtyas, D. 2014. Using Peer Revision Technique to Improve Learners' Writing Skill at Grade VIIII of SMP N 3 Kota Bengkulu.UniversitasBengkulu: Unpublished Thesis

Oliver, R. 2002. The patterns of negotiation for meaning in child interaction. Modern Language Journal, 86, 97-111

Oxford English Dictionary. 7th ed. Oxford: Oxford University Press, 2007.

Richard, J. et al. 2002. Longman Dictionary of Language Teaching and Applied Linguistics, ( $3^{\text {rd }}$ edition). London: Pearson Education.

Rollinson, P. 2005. Using peer feedback in the ESL writing class.ELT Journal, 59, 23-30.

Schwartz, K. 2013. Teaching Strategies:7 Essential Principles of Innovative Learning. $\quad$ http://ww2.kqed.org/mindshift/2013/02/01/7-essentialprinciples-of-innovative-learning/, retrieved on May 2015 
50| ELT Worldwide Vol. 3 No. 1 April 2016

Sukandi, S.S. 2014.Teaching Writing To Indonesian EFL Learners Challenges Of The 'Voice' And 'Style' inAdjustingCross Cultural Communication Skills. Seminar of Language teaching in cross-cultural context. http://www.academia.edu/5838001/Teaching_Writing_to_Indonesian_EFL_Le arners_Challenges_of_the_Voice_and_Style_in_Adjusting_Cross_Cultural_Co mmunication_Skills, Retrieved on January 2015.

Teo, A. K. 2006. Using a Peer Assisted Writing Activity to Promote ESL/EFL Learners' Narrative Writing Skills. The Internet TESL Journal, Vol. XII.

Topping, K.,et al. 2000. Formative peer assessment of academic writing between postgraduate learners.Assessment and Evaluation in Higher Education, 25(2), 149-169.

Winer, L. 1992."Spinach to Chocolate": Changing Awareness and Attitude in ESL Writing Teachers." TESOL Quarterly 26: 57-79.

Zulharman. 2008. Peran self-directed learning readiness pada prestasi belajar mahasiswa tahun pertama Fakultas Kedokteran Universitas Riau. Yogyakarta: Universitas GadjahMada

http://psychology.about.com/od/sensationandperception/ss/perceptproc. $\mathrm{htm}$, retrieved on May 2015

http://www.gifted.uconn.edu/Siegle/SchoolPerceptions/printversion.pdf retrieved on May 2015 